Orissa Journal of Commerce

Vol. 42, Issue 1, Jan-March 2021

ISSN: 0974-8482

(C) OJC India. All Right Reserved

URL : www.ojcoca.org

DOI: https://doi.org/10.54063/ojc.2021.v42i01.10

\title{
Examining the Behavioural and Attitudinal Purchase Intentions of Youth Toward Green Products
}

\author{
Vishal Gupta \\ Lecturer, Government College for Women Parade, Jammu, Jammu and Kashmir. E-mail:vishalm.com85@gmail.com
}

\author{
To cite this paper \\ Gupta, V. (2021). Examining the \\ Behavioural and Attitudinal \\ Purchase Intentions of Youth \\ Toward Green Products. Orissa \\ Journal of Commerce. 42(1), 132-148.
}

Keywords

Green products, Purchase intentions, Purchase behaviour, Green advertising, Green loyalty, Green satisfaction.

JEL Classification M3, D16, D19

\begin{abstract}
This paper studied the relationship between attitude towards green products, green purchase intentions and green purchase behavior of young Indian consumers through a model based on the theory of planned behavior. 1110 questionnaires were distributed among the students of three north Indian Universities for the data collection. The various anticipated relationships among the variables in the proposed model were tested via structural equation modeling in AMOS 24. The various anticipated relationships among the study variables were by and large supported. The study will prop up the green consumption by offering valuable insights to the companies and government for devising strategic green marketing mix and framing the suitable legal green policies.
\end{abstract}

\section{Introduction}

Green product consumption has developed into a new-fangled global movement among consumers due to its pro-health benefits and pro-sustainable development features (Leonidou et al., 2013). Over the past decades, green consumption started getting progressive attention in the academic and business world (Junior et al., 2015). Green initiatives have emerged in almost every sector of the marketplace including automotive, electronics, durable goods, energy, healthcare, food products. Global companies have also been able to capitalise on the green philosophy by adopting an attractive brand image and using it as a competitive weapon for an expanded market (Moravcikova, et al., 2017).Companies have rethought their product mixing strategies in various forms ranging from recycled products to the products with natural or plant based ingredients (Uddin and Khan, 2018). For instance, companies such as Apple, Himalaya, Godrej, Dabur, Classmate, Maruti, Nutrilite, Samsung, HCL, LG, etc. have started to manufacture green labels products, organic products, recycled products and certified products that meet the environmental accountability criteria for magnetising green consumers (Tyagi, 2013).

As the youngest country in the world, with a labour force of one billion by 2027, India can make a significant contribution to environmental improvement and protection (Jain and Kaur, 2011). For 
the intensive promotion of green products among the Indian youth, marketing experts have consistently framed strategies to evaluate their attitude and behaviour towards green products (Sujith, 2017). As a consequence of this green wave, attitude and behaviour of Indian consumers towards green products have come out as a force to consider as a part of the accelerating green marketing expansion and have become a focus of marketing research. Therefore, an extensive study is being conducted on the attitude and purchasing behaviour of Indian youth towards green products to secure India's economic, industrial and infrastructure development in a green and sustainable manner.

\section{Review of Literature}

Earlier research studies on green products consumption confirmed that due to the positive level of attitude towards ecological safety among the consumers, there is a upsurge in the green products demand (Paul et al., 2016; Yadav and Pathak, 2016; Schmeltz, 2012). But, In spite of this enhanced attitude and willingness of people to buy green products, the green products market share often stayed very little in comparison to the conventional products' share (Bray, Johns and Killburn, 2011; Moser, 2015). During the last few decades, a number of studies have explored the green purchase behaviour and reported a "gap" between the optimistic attitude of consumers regarding green products and tangible purchasing of green products, nevertheless no authoritative justification has yet been found (Carrington et al., 2010; Nilson, 2016; Nguyen et al., 2019). It implied that the positive attitude of consumers towards green products does not frequently decode into the ultimate purchase of green products. Regardless of significant extant literature on green consumption attitude, intention and behavior, the number of theoretical model-based researches to analyse the influence of the potential factors on the relationship between attitude towards green products (AGP), green purchase intentions (GPI) and Green Purchase Behavior (GPB) are still minute. The present study is an effort to determine these factors to make possible for the marketers to push consumers to purchase green products in reality. Based on the theory of planned behavior (TPB) given by Ajzen in 1991, this study tried to comprehend the green purchase behavior of young Indian consumers. Theory of planned behaviour is the one of the most prominent and frequently citied model in explaining the multifaceted and unpredictable human behaviour. This theory put forwarded that the attitude, Subjective Norms (SN) and Perceived Behavioural Control (PBC) control intention, and subsequently this intention predicts the actual behaviour.

In the past, TPB has been used in different research contexts, like, exploring sustainable tourism (Antimova et al., 2012), knowledge sharing (Nguyen et al., 2019), participation of union workers in employee involvement (Dawkins and Frass, 2005), fan involvement behaviour in baseball (Cheng et al., 2012) and effectiveness of higher education institution (Lertpratchya, 2017). Moreover, TPB is also being applied and confirmed in perspective of green purchase behavior or environmental behavior in several studies (Tenkasi and Zhang, 2018; Paul et al., 2016; Liu and Liu, 2020; Sharma and Foropon, 2019). The present study extended the TPB model by incorporating seven additional variables found in literature, namely, perceived benefits, green advertising, perceived consumer effectiveness, environmental concern, green washing, green satisfaction and green loyalty in the model. These factors are further discussed as under: 


\subsection{Environmental Concern (EC)}

EC denotes the upbeat concern of an individual for the environmental problems (Kim and Choi, 2005). In the past, various studies on green purchase behavior such as, Paul et al., (2016), Diamantopoulos et al., (2003), Chen and Tung (2014), and Prakash and Pathak (2016) reported the positive impact of EC on AGP.

\subsection{Perceived Benefits (PB)}

Apart from environment shielding criteria, people are also in the hunt for personal returns from the usage of green products and these personal benefits, personal concern or self-interest includes reasonable prices, quality, healthy features, easy availability etc. (Drennan et al., 2006). Researchers like Ahmad and Thyagaraj (2018) and Davis (2012) confirmed that self expressive benefits availed from the green products had positive impact on the AGP.

\subsection{Green Advertising (GA)}

Green advertising is a advertising strategy used for the promotion of green products for the environmental and human health protection. Green advertisements infuse positive attitude among consumer towards green products and eventually transform this constructive attitude into the green purchase behavior (Davis, 1994; Rahbar and Wahid, 2011; Chase and Smith, 1992; Chan, 2004).

\subsection{Perceived Consumer Effectiveness (PCE)}

In general sense, PCE refers to a belief of a human being that his/her efforts can contribute towards the resolution of a certain crisis (Gonzalez et al., 2015; Gleim et al., 2013). Some studies on green product consumption have established a noteworthy impact of PCE on the attitude of consumers towards green products (Emecki, 2019)

\subsection{Greenwashing (GW)}

Greenwashing refers to the action of making overstated or deceptive green claims by the company in order to capture more market share (Dahl, 2010; Laufer, 2003). Chen and Chang (2013) found that the embracing of greenwashing by the companies to make the most of the new green consumption wave usually resulted in the zero sales of the product due to the negative connection with attitude.

\subsection{Attitude towards Green Products (AGP) and Green Purchase Intentions (GPI)}

Attitude as a key predictor of behavioral intentions refers to extent of positive or negative people's reactions arising out of the evaluation of the behaviour (Kotchen and Reiling 2000). Various research studies on green consumer psychology found that the optimistic AGP results in the stronger GPI (Thi Tuyet Mai, N. 2019; Sukhi, 2016). 
Examining the Behavioural and Attitudinal Purchase Intentions of Youth Toward Green Products

\subsection{Subjective Norms (SN)}

Subjective norm (SN) signifies the views or motivation to comply of an individual about the expectations of his/her referent groups such as family, friends, coworkers etc. (Ajzen, 1991; Baker et al., 2007). Several studies have recognised the SN as a key predictor of GPI (Teng et al., 2014; Thi Tuyet Mai, N. 2019; Yadav and Pathak, 2017; Ko and Jin, 2017). But the researchers like Paul et al. (2016) and Khare (2015) found no influence of SN on GPI.

\subsection{Perceived Behavioural Control (PBC)}

PBC refer to the perception of people about the barriers or self-efficacy to execute a certain performance and it emphasises the significance of situational constraints (Ajzen, 2002; Bamberg and Möser, 2007). In the existing literature, constructive rapport between PBC and GPI has been established in different perspective (Nguyen et al., 2019).

\subsection{Green Purchase Intentions (GPI) and Green Purchase Bebavior (GPB)}

As a general canon, attitude and intentions are perceptible responses and the behaviour is considered as some concrete action by the people (Kim and Choi, 2005). In conformity with the theory of planned behaviour, behavior can be estimated from intentions with significant precision (Ajzen, 1991; Moisander, 2007).

\subsection{Green Satisfaction (GS) and Green Loyalty (GL)}

Asgharian et al. (2012) described the green satisfaction as a pleasing experience resulted from the comparison of expected performance the real perceived performance of green products. Oliver (1999) termed green loyalty as a keenness to frequently rebuy a product or service regardless of the supremacy of conditions and strong marketing promotional efforts by firms' competitors. Furthermore, the academic literature related to green consumption has supported the positive relationship among GS and GL (Chen, 2010; Asgharian, 2012; Chang and Fong 2010; Martenson, 2007).

\section{Hypotheses of the Study}

Recent studies on green product consumption (Ahmed and Zhang, 2020; Marvi et al., 2020; Chairy and Syahrivar, 2020; Zhang and Dong, 2020) are not so comprehensive and normally constrained to only one aspect of green consumer psychology i.e. AGP, GPI or GPB. Moreover, very few studies have focused on youth segment (15-29 years) which is rapid growing, moderniser, choosy and interested in innovative product configuration etc.

On the basis of review of literature, following hypotheses are developed:

$\mathrm{H}_{1}$ : EC significantly affects the AGP.

$\mathrm{H}_{2}:$ PB significantly affects the AGP.

$\mathrm{H}_{3}$ : GA significantly affects the AGP.

$\mathrm{H}_{4}$ : PCE significantly affects the AGP.

$\mathrm{H}_{5}$ : GW negatively affects the AGP. 
$\mathrm{H}_{6}$ : $\quad$ AGP directly leads to GPI.

$\mathrm{H}_{7}$ : GPI is significantly predicted by $\mathrm{SN}$ and PBC.

$\mathrm{H}_{8}$ : GPI directly leads to GPB.

$\mathrm{H}_{9}$ : GPB is significantly predicted by GS and GL.

$\mathrm{H}_{10}$ : GS leads to the GL.

\section{Research Methodology}

\subsection{Research Techniques}

The data were collected from the post graduate students of three north Indian Universities namely, University of Jammu (Jammu and Kashmir), Himachal Pradesh University (Himachal Pradesh) and Guru Nanak Dev University (Punjab) through questionnaire survey. A total of 1110 questionnaire were distributed for final survey using purposive sampling criteria being usage of green products in the last one year (2019) and willingness to fill the questionnaire. Out of the 1110 distributed questionnaires, 947 questionnaires are returned which account for approximately $85 \%$ of the response rate which is considered adequate for analysis (Hair et al. 2010). Out of 947 returned questionnaires, about 42 questionnaires are found to be ineffective because of either incomplete response or similar response patterns to each item. Finally, 905 questionnaires $(81 \%)$ are found to be useable for further analysis. In order to further normalize the data, 41 respondents were detected as outliers on the basis of box plot, which reduced the sample to 864 . Table 1 presents a brief profile of the respondents with respect to gender, department, annual family income and region.

Table 1: Descriptive Profile of the Respondents

\begin{tabular}{|c|c|c|c|c|}
\hline S. No & Variables & Classification & Frequency & Percentage (\%) \\
\hline \multirow[t]{3}{*}{1} & \multirow[t]{3}{*}{ State } & University of Jammu, Jammu, Jammu and Kashmir & 298 & 35 \\
\hline & & Guru Nanak Dev University, Amritsar, Punjab & 296 & 34 \\
\hline & & Himachal Pradesh University, Shimla, Himachal Pradesh & 270 & 31 \\
\hline \multirow[t]{2}{*}{2} & \multirow[t]{2}{*}{ Gender } & Male & 390 & 45 \\
\hline & & Female & 474 & 55 \\
\hline \multirow[t]{4}{*}{3} & \multirow{4}{*}{$\begin{array}{l}\text { Annual } \\
\text { family } \\
\text { income }\end{array}$} & Below ₹100000 & 187 & 22 \\
\hline & & ₹100000-₹300000 & 242 & 28 \\
\hline & & ₹300000-₹500000 & 258 & 30 \\
\hline & & Above ₹500000 & 177 & 20 \\
\hline
\end{tabular}

Source: Primary Survey

\subsection{Generation of Scale}

After appraising the related literature, five dimensions of AGP, two dimensions of GPI and two dimensions of GPB were elicited and these dimensions were measured with 38 item-scale. The study 
used already validated scales with 5 -point Likert scale items arraying from $1=$ strongly disagree to $5=$ strongly agree. EC was assessed via a five-item scale adopted from Straughan and Roberts (1999). For measuring PB, four-items were adopted from Wu and Chen (2014).Further GA was measured using Chan's (2006) four-item scale. In order to measure the PCE, 4 items were taken from Straughan and Roberts (1999). Three-items for measuring SN and four items for measuring PBC were adapted from Paul, Modi and Patel (2016). To measure the greenwashing, green satisfaction and green loyalty fourteen items were taken from Braga et al. (2016) and Correa et al. (2017).

\section{Data Analysis}

Initially, confirmatory factory analysis (CFA) was conducted to check the validity and to validate the goodness of fitness of all the scales in the current framework. Subsequently, proposed model fitness was evaluated using structural equation modeling (SEM) through various standard indicators such as comparative fit index (CFI), root mean square residual (RMR), goodness-of-fit index (GFI), adjusted GFI (AGFI), and root mean square error of approximation (RMSEA), chi-square to degree of freedom ratio $\left(\mathrm{x}^{2} / \mathrm{df}\right)$.

\subsection{Measurement Model}

Single order models have been generated for the nine latent constructs tested using CFA (Table 2). Four items (EC5, PCE4, GW1 and PBC3) were deleted due to low factor loading. In an attempt to estimate the discriminant validity, comparison has been made among the average variance extracted (AVE) and squared correlation between the constructs used in this study (Hair et al., 2010). AVE of all constructs is larger than the squared correlations, which too confirmed the discriminant validity (Table 3). Table 2 demonstrated that standardised estimate (SE) and AVE are larger than 0.5 and thereby established convergent validity (Anderson and Gerbing, 1988). Besides this, Cronbach's alpha and composite reliability (CR) has been calculated to confirm the reliability. Table 2 showed that the value of Cronbach's alpha and the value of CR for all the constructs is above is greater than 0.70 .

\subsection{Structural Model}

The structural liaison between the various latent constructs (Table 4) was examined through SEM (AMOS 24). The results of SEM (Figure 1) analysis revealed the highest contribution of EC (SRW=.71, $\mathrm{p}<.001)$ in the formation of positive AGP virtually followed by PCE (SRW=.70, $<<.001), \mathrm{PB}$ $(\mathrm{SRW}=.64, \mathrm{p}<.05)$ and GA $(\mathrm{SRW}=.58, \mathrm{p}<.001)$. But the negative impact of $\mathrm{GW}(\mathrm{SRW}=-.38, \mathrm{p}<$ $.005)$ was reported on AGP. The model also traced a significant impact of $\mathrm{SN}(\mathrm{SRW}=.55, \mathrm{p}<.005)$ and $\mathrm{PBC}(\mathrm{SRW}=.63, \mathrm{p}<.005)$ on IGP. The results also specified that $\mathrm{GS}(\mathrm{SRW}=.76, \mathrm{p}<.001)$ and $\mathrm{GL}(\mathrm{SRW}=$ $.64, \mathrm{p}<.005)$ are positively related to GPB and moreover GL is reported to have positive impact on GS $(\mathrm{SRW}=.56, \mathrm{p}<.005)$. Further the relationships between AGP and IGP $(\mathrm{SRW}=.75, \mathrm{P}<0.05)$ and IGP and $\mathrm{GPB}(\mathrm{SRW}=.66, \mathrm{p}<0.05)$ are also found to be significant. In spite of the poor model fitness, the result confirmed the significant relationships between all the constructs and latent constructs. So, to improve the model fitness modification indices (MI) have been inspected. The modification values from EC to GL $(M I=155.33)$ and $G W$ to $G P B(M I=223.11)$ are very high $(>90)$ has been introduced 


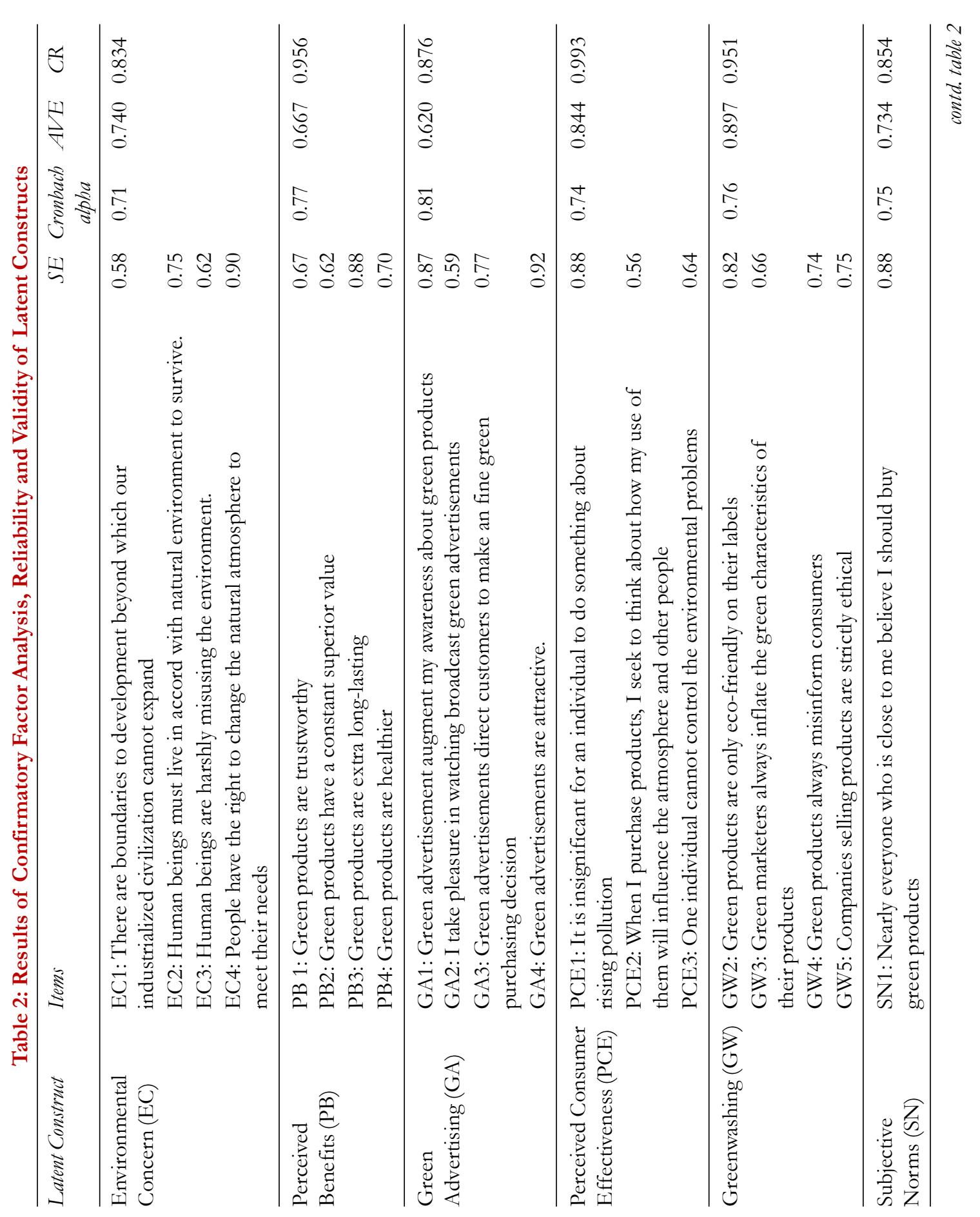


Examining the Behavioural and Attitudinal Purchase Intentions of Youth Toward Green Products

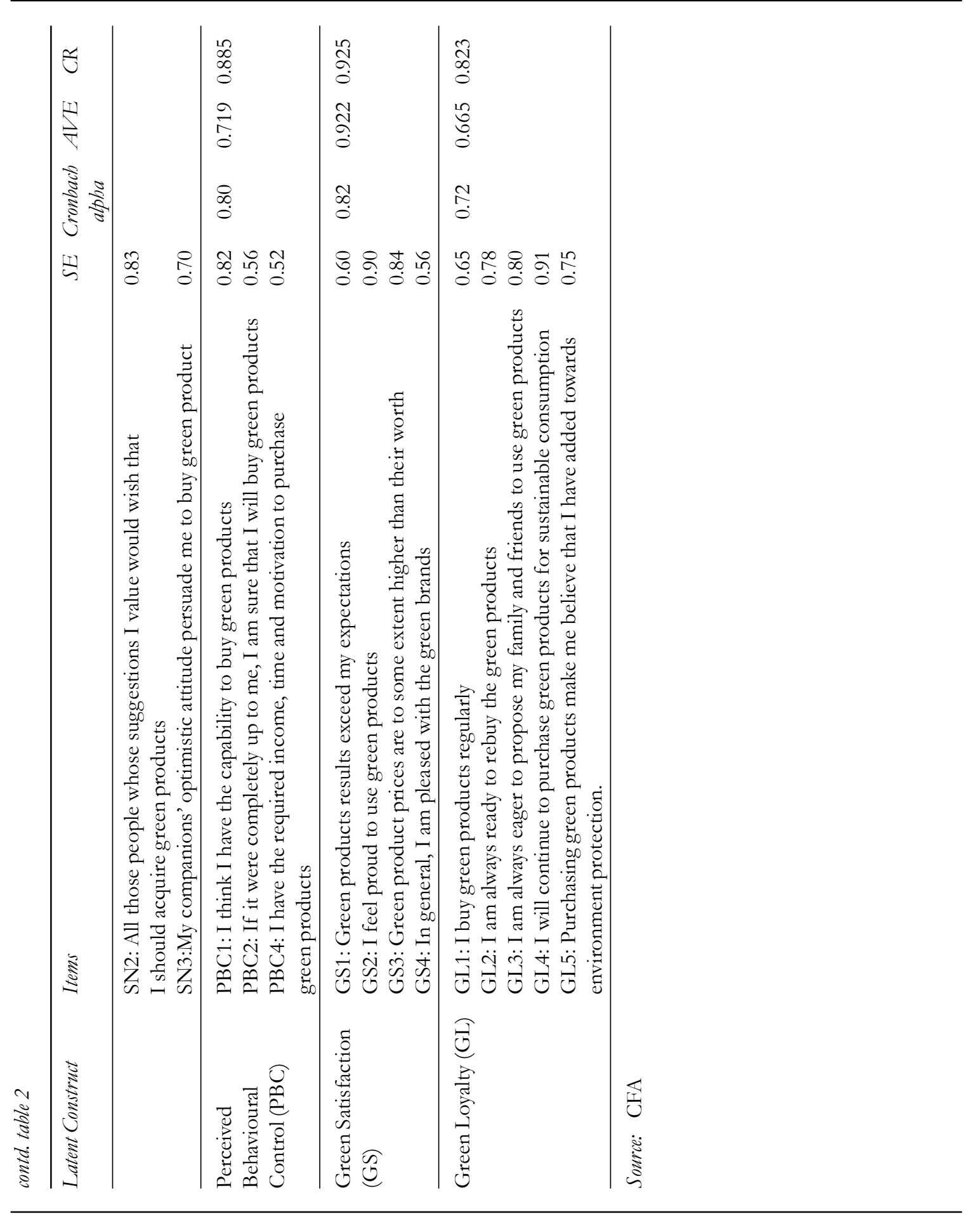

Orissa Journal of Commerce, 42(1) (C) 2021 


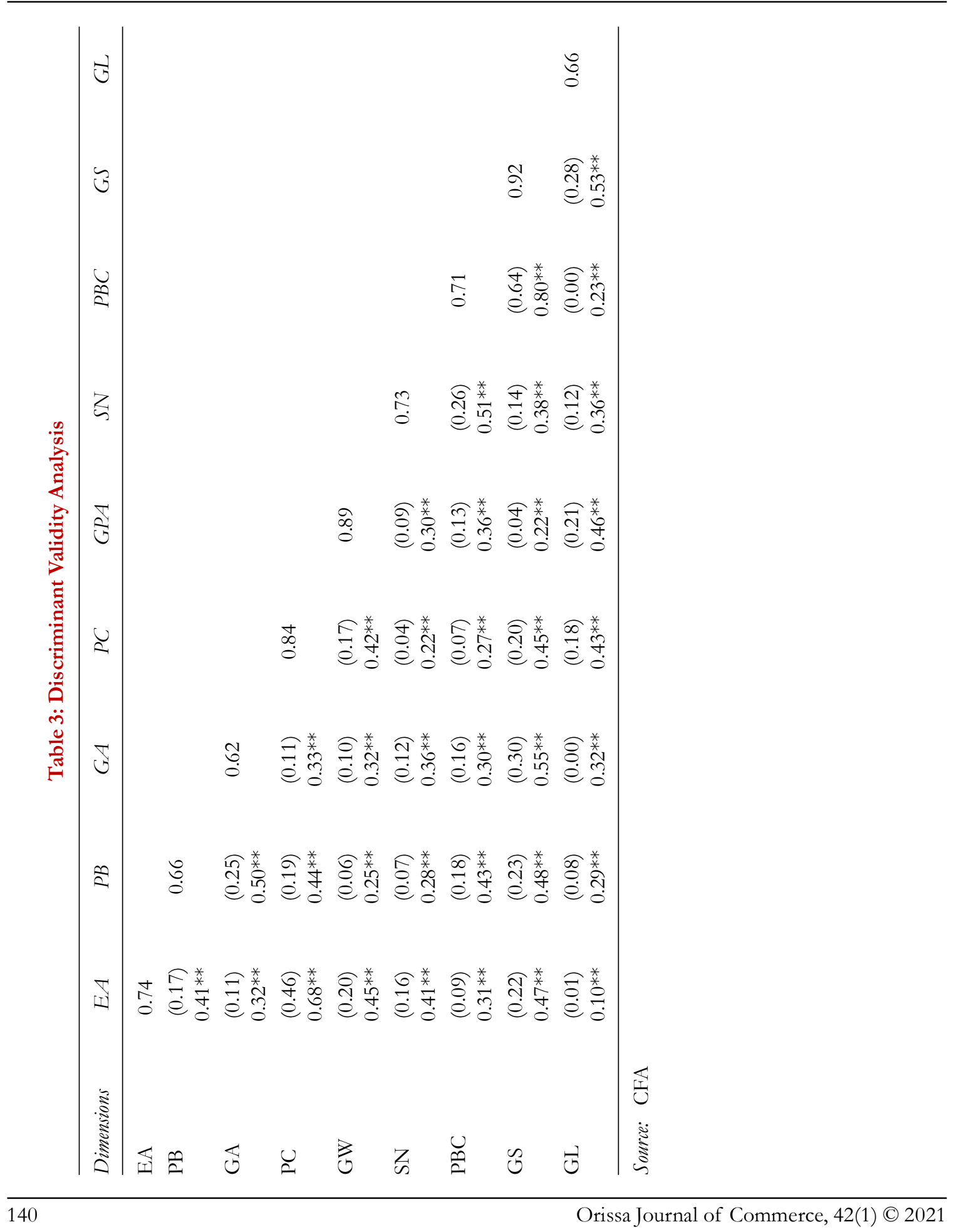


which improved the model fitness $(\mathrm{CMIN} / \mathrm{DF}=4.813, \mathrm{RMR}=0.047, \mathrm{GFI}=.723, \mathrm{AGFI}=.849, \mathrm{CFI}$ $=.911$, RMSEA $=0.064$ ). So, all the hypotheses $\mathrm{H}_{1}$ (relationship between AGP and EC), $\mathrm{H}_{2}$ (relationship between AGP and PB), $\mathrm{H}_{3}$ (relationship between AGP and GA), $\mathrm{H}_{4}$ (relationship between AGP and PCE), $\mathrm{H}_{5}$ (negative relationship between AGP and GW), $\mathrm{H}_{6}$ (relationship between AGP and IGP), $\mathrm{H}_{7}$ (relationship of SN and PBC with IGP), $\mathrm{H}_{8}$ (relationship between IGP and GPB), $\mathrm{H}_{9}$ (relationship between GPB and GS and GL) and $\mathrm{H}_{10}$ (relationship between GS and GL) stand accepted at the integrated level.

Table 4: Structural Model Results

\begin{tabular}{|c|c|}
\hline Latent Constructs & Fit Indices \\
\hline \multirow[t]{6}{*}{ EA } & $\chi^{2} / \mathrm{df}=4.265$ \\
\hline & $\mathrm{RMR}=0.034$ \\
\hline & $\mathrm{GFI}=0.961$ \\
\hline & AGFI $=0.929$ \\
\hline & $\mathrm{CFI}=0.959$ \\
\hline & RMSEA $=0.066$ \\
\hline \multirow[t]{6}{*}{ PB } & $\chi^{2 / \mathrm{df}}=3.812$ \\
\hline & $\mathrm{RMR}=0.017$ \\
\hline & $\mathrm{GFI}=0.983$ \\
\hline & $\mathrm{AGFI}=0.969$ \\
\hline & $\mathrm{CFI}=0.987$ \\
\hline & RMSEA $=0.056$ \\
\hline \multirow[t]{6}{*}{ GA } & $\chi^{2} / \mathrm{df}=3.644$ \\
\hline & $\mathrm{RMR}=0.033$ \\
\hline & $\mathrm{GFI}=0.954$ \\
\hline & $\mathrm{AGFI}=0.917$ \\
\hline & $\mathrm{CFI}=0.944$ \\
\hline & RMSEA $=0.069$ \\
\hline \multirow[t]{6}{*}{ PCE } & $\chi^{2 / \mathrm{df}}=4.087$ \\
\hline & $\mathrm{RMR}=0.050$ \\
\hline & $\mathrm{GFI}=0.986$ \\
\hline & $\mathrm{AGFI}=0.939$ \\
\hline & $\mathrm{CFI}=0.977$ \\
\hline & RMSEA $=0.075$ \\
\hline \multirow[t]{6}{*}{ GW } & $\chi 2 / \mathrm{df}=2.538$ \\
\hline & $\mathrm{RMR}=0.025$ \\
\hline & $\mathrm{GFI}=0.977$ \\
\hline & $\mathrm{AGFI}=0.935$ \\
\hline & $\mathrm{CFI}=0.974$ \\
\hline & RMSEA $=0.071$ \\
\hline
\end{tabular}




\begin{tabular}{|c|c|}
\hline Latent Constructs & Fit Indices \\
\hline \multirow[t]{6}{*}{ SN } & $\chi^{2} / \mathrm{df}=4.226$ \\
\hline & $\mathrm{RMR}=0.046$ \\
\hline & $\mathrm{GFI}=0.983$ \\
\hline & AGFI $=0.955$ \\
\hline & $\mathrm{CFI}=0.986$ \\
\hline & RMSEA $=0.060$ \\
\hline \multirow[t]{6}{*}{$\mathrm{PBC}$} & $\chi^{2 / \mathrm{df}}=3.010$ \\
\hline & $\mathrm{RMR}=0.018$ \\
\hline & $\mathrm{GFI}=0.990$ \\
\hline & AGFI $=0.966$ \\
\hline & $\mathrm{CFI}=0.992$ \\
\hline & RMSEA $=0.047$ \\
\hline \multirow[t]{6}{*}{ GS } & $\chi 2 / \mathrm{df}=3.469$ \\
\hline & $\mathrm{RMR}=0.018$ \\
\hline & $\mathrm{GFI}=0.983$ \\
\hline & AGFI $=0.955$ \\
\hline & $\mathrm{CFI}=0.984$ \\
\hline & RMSEA $=0.044$ \\
\hline \multirow[t]{6}{*}{ GL } & $\chi^{2 / d f}=4.613$ \\
\hline & $\mathrm{RMR}=0.045$ \\
\hline & $\mathrm{GFI}=0.972$ \\
\hline & AGFI $=0.925$ \\
\hline & $\mathrm{CFI}=0.972$ \\
\hline & RMSEA $=0.072$ \\
\hline Integrated Relationship & $\chi^{2 / d f}=4.813$ \\
\hline \multirow[t]{5}{*}{ between All Constructs } & $\mathrm{RMR}=0.047$ \\
\hline & $\mathrm{GFI}=0.723$ \\
\hline & AGFI $=0.849$ \\
\hline & $\mathrm{CFI}=0.911$ \\
\hline & RMSEA $=0.064$ \\
\hline
\end{tabular}

Source: CFA and SEM

\section{Findings}

The study further extended the relevance of TPB structure in understanding the integrated relationship between AGP, IGP and GPB of Indian consumers. The outcomes are similar to the established conventions in the GPB literature that AGP is directly or indirectly impacted by the EC (Prakash and Pathak, 2016; Junior et al. 2015), the personal benefits from the usage of green products (Junior et al., 


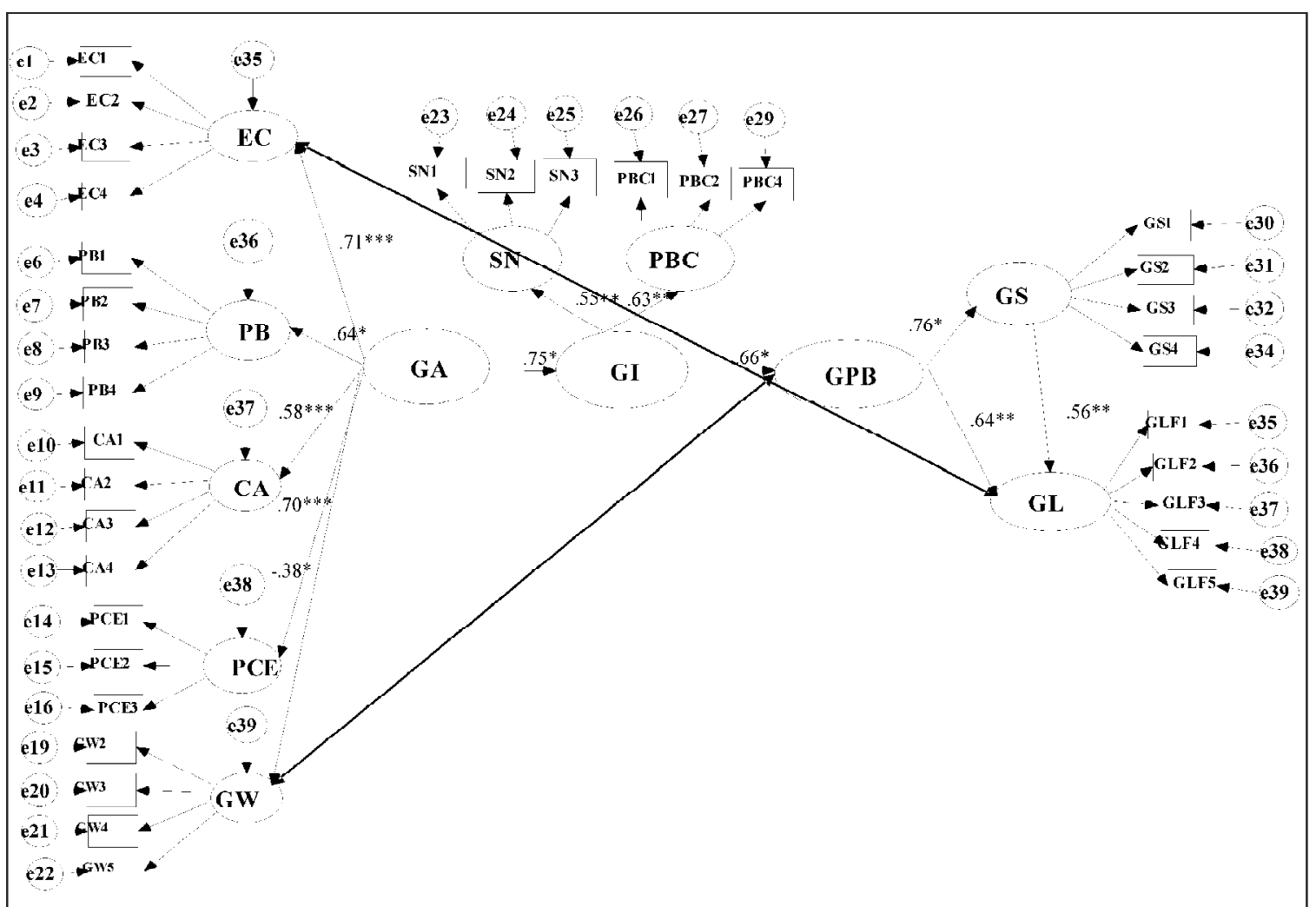

Figure 1: Structural Relationship between AGP, GPI and GPB

Source: Author's Calculation

2019), GA (Sarkar et al., 2019) and PCE (Mishal et al., 2017). Due to the prevailing pessimistic AGP, companies have started using GW as a tool to take benefit of this green consumption wave (Chen and Chang, 2013; Junior et al. 2019). The study also confirmed the negative impact of GW on AGP (Leonidou et al., 2011). For that reason, government should scan the promotional strategies of the companies and punish the companies applying greenwashing as a weapon to attract green consumers (Nguyen $e t$ al. 2019). These insights accentuated that green drives should be organised at schools, colleges and universities to boost the environment concern of the youth. The marketers should start campaigns about the personal benefits of the green products like cost-savings, quality, non-exposure to toxic chemicals, use of natural ingredients etc. In order to reckon the firm trust of respondents on green advertising, the green marketers should use innovative advertisements with green messages through television media, radio, digital media, print media, celebrity advertising etc.

Furthermore, the study like some previous studies (Yadav and Pathak, 2017; Paul et al., 2016) established SN and PBC as the important forecaster of GPI. Marketers should organise campaigns to guide the parents to develop green habits among children like switch off the lights and appliances 
while not in use, taking the bus to work, recycle the paper, glass and metals etc. to inculcate the regular habits of green consumption among upcoming consumers. Furthermore, the present study has established the positive connection between IGP and GPB (Mishal et al. 2017; Junior et al. 2015; Nguyen, Le, et al., 2017). Under the latent construct PBC, the study found that consumers are worried about the lack of availability and high prices of green products. So, the green marketers should adopt intensive distribution strategy in conjunction with apt pricing strategy. Online green product companies like other prominent online shopping companies viz Flipkart, Amazon, Snapdeal etc. can make possible for the consumers to avail green products at the door steps without losing much time.

The findings related to the positive influence of GS and GL on GPB are also analogous to the previous studies like Chang and Fong (2010) and Saeednia et al. (2012). The study like some previous studies (Saeednia et al., 2012; Chang and Fong, 2010; Gountas and Gountas, 2007) also established a substantial association between GS and GL. In this regard, upbeat views of regular and trusted users of green products should be exhibited in print and digital media to exert a pull on new customers and appreciate the loyal customers. Even the companies can publish the photo and positive reviews of green committed consumers in the monthly company magazines to boost the future green purchases.

\section{Conclusion}

With the moderate level of environmental concern among the consumers, high demand for personal benefits, rising popularity of green advertising, altruistic philosophy of the consumers and negative connection with GW, the AGP is proved to be a vital predictor of GPI and GPB. Hence, it is propelling the marketers to introduce new green products with authentic pro-environmental claims to fulfill the basic needs of the consumers along with the environmental benefits. To create the stronger GPI, the marketers should adopt extensive logistics policies, rigorously disseminate the green product information and set reasonable price for the green products. To make the consumers more satisfied and loyal toward green products the manufacturers should add more healthy green ingredients to the products, introduce new range of green products with more eco-friendly features and contents, add more varieties to the choice of green products and appreciate the green commitments of consumers.

\section{References}

Ahmad, A., and Thyagaraj, K.S. (2018). Consumer's intention to purchase green brands: The roles of environmental concern, environmental knowledge and self-expressive benefits. Current World Environment, 10(3), 879-889.

Ahmed, W. and Zhang, Q. (2020). Green purchase intention: Effects of electronicservice quality and customer green psychology. Journal of Cleaner Production, doi: https://doi.org/10.1016/j.jclepro.2020.122053.

Ajzen, I. (2002). Perceived behavioral control, self-efficacy, locus of control, and the theory of planned behavior. Journal of Applied Social Psychology, 32(4), 665-683.

Ajzen, I. (1991). The theory of planned behaviour. Organisational Behaviour and Human Decision Processes, 50 (1), 179-211.

Akehurst, G., Carolina, A., and Helena, M.G.(2012). Re examining green purchase behaviour and the green consumer profile: New evidences. Management Decision, 50(5), 972-988. 
Anderson. J., and Gerbing, D. (1988). Structural equation modeling in practice: A review and recommended twostep approach. Psychological Bulletin, 103(3), 411-423.

Antimova, R., Nawijn, J.,and Peeters, P. (2012). The awareness/attitude-gap in sustainabletourism: a theoretical perspective. Tourism Review, 67(3), 7-16.

Asgharian, R., Salehi, M., Saleki, Z.S., Hojabri, R., and Nikkheslat, M. (2012). Green product quality, green customer satisfaction and green customer loyalty. International Journal of Research in Management and Technology, 2(5), 499-503.

Baker C. W., Little T. D., and Brownell K. D. (2003). Predicting adolescent eating and activity behaviours: the role of social norms and personal agency. Health Psychology, 22 (1), 189-198.

Bamberg, S. and Möser, G. (2007). Twenty years after Hines, Hungerford, and Tomera: a new meta-analysisof psycho-social determinants of pro-environmental behaviour. Journal of Environmental Psychology, 27 (1), 1425.

Braga, S.S., Jr, Merlo, E.M., Freire, O.B.L., Da Silva, D., and Quevedo-Silva, F. (2016). Effect of environmental concern and skepticism in the consumption green products in brazilian retail. Espacios, 37(2), 13-23.

Bray, J., Johns, N., and Kilburn, D. (2011). An exploratory study into the factors impeding ethical consumption. Journal of Business Ethics, 98(4), 597-608.

Carrington, M. J., Neville, B. A., and Whitwell, G. J. (2010). Why ethical consumers don't walk their talk: Towards a framework for understanding the gap between the ethical purchase intentions and actual buying behaviour of ethically minded consumers. Journal of Business Ethics, 97(1), 139-158.

Chan, R.Y.K. (2004). Consumer responses to environmental advertising in China. Marketing Intelligence and Planning, 22 (4), 427-37.

Chandon, P., Wansink, B., and Laurent, G. (2000). A benefit congruency framework of sales promotioneffectiveness. Journal of Marketing, 64, 65-81.

Chang, J.N., and Fong, C. (2010). Green product quality, green corporate image, green customer satisfaction and green customer loyalty. African Journal of Business Management, 4(13), 2836-2844.

Chairy, C. and Syahrivar, J. (2020). You reap what you sow: The role of Karma in Green purchase. Cogent Business and Management, 7(1), 1798066

Chase, D. and Smith, T.K. (1992). Consumers keen on green but marketers don't deliver. Advertising Age, 63 (26), $2-4$.

Chen YS (2010). The driver of green brand equity: green brand image, green satisfaction, and green trust. Journal of Business Ethics, 92(3), 307-319.

Chen, Y.S., and Chang, C.H. (2013). Greenwash and green trust: The mediation effects of green consumer confusion and green perceived risk. Journal of Business Ethics, 114, 489-500.

Cheng, C.-F., Chen, L.H., Chen, M.-Y. and Lu, W.-C. (2012). Fan participation behaviour in baseball: an application of the theory of planned behaviour. International Journal of Sports Marketing and Sponsorship, 14(1), 17-28.

Chen, M. F. and Tung, P. J. (2014). Developing an extended theory of plannedbehavior model to predict consumers' intention to visit green hotels. International Journal of Hospitality Management, 36 (1), 221-230.

Correa, C., Junior, S., and Da Silva, D. (2017). The social control exerted by advertising: A study on the perception of greenwashing in green products at retail. British Journal of Education, Society and Behavioural Science, 19, 1-9. 
Dahl, R. (2010). Green washing: Do you know what you're buying. Environmental Health Perspectives, 118, 246-252.

Davis, I. (2012). How (not) to market socially responsible products: A critical research evaluation. Journal of Marketing Communications, 2(1), 1-15.

Davis, J.J. (1994). Consumer response to corporate environmental advertising. Journal of Consumer Marketing, 11 (2), 25-37.

Dawkins, G.E., and Frass, J.W. (2005). Decision of union workers to participate in employeeinvolvement: an application of the theory of planned behaviour. Employee Relations, 27(5), 511-531.

Diamantopoulos, A., Schlegelmich, B.B., Sinkovics, R.R. and Bohlen, G.M. (2003). Can socio-demographics still play a role in profiling green consumers? A review of the evidence and an empirical investigation. Journal of Business Research, 56 (6), 465-480.

Drennan, J., Sullivan Mort, G., and Previte, J. (2006). Privacy, risk perception, and expert online behavior:An exploratory study of household end users. Journal of Organizational and End UserComputing (JOEUC), 18, 1 22.

Ellen, S.P., Wiener, J.J., and Walgren, C.C. (2016). The Role of Perceived Consumer Effectiveness in Motivating Environmentally Conscious Behaviors. Journal of Public Policy and Marketing, 10 (2), 102-117.

Emekci, S. (2019). Green consumption behaviours of consumers within the scope of TPB. Journal of Consumer Marketing, 36 (3), 410-417.

Gleim, M. R., Smith, J. S., Andrews, D., and Cronin, J. J. (2013). Against the green: A multi method examination of the barriers to green consumption. Journal of Retailing, 89(1), 44-61.

Gonzalez, A.P., Miguens, M.J.L., and Vazquez, G.E. (2015). The ecological consumer's profile in Spain. EsicMarket Economics and Business Journal, 46 (2), 241-268

Gountas, J., and Gountas, S. (2007). Personality orientations, emotional states, customer satisfaction, and intention to repurchase. Journal of Business Research, 60(1), 72-75.

Hair, J.F., Black, W.C., Babin, B.J. and Anderson, R.E. (2010). Multivariate Data Analysis: A Global Perspective.7th ed., Pearson Education Inc., Essex, NJ.

Jain, K.S., and Kaur, G. (2011). Green marketing: An attitudinal and behavioural analysis of Indian consumers. Global Business Review, 5(2), 188-205.

Junior, S.B., Martínez, M.P., Correa, C.M., Moura-Leite, R.C., and Da Silva, D. (2019). Greenwashing effect, attitudes, and beliefs in green consumption. RAUSPManagement Journal,doi: org/10.1108/RAUSP-082018-0070.

Juniora,S.S.B., Silvab, D.D., Gabrielb, D. S.M., and Braga, W.R.O.D. (2015). The effects of environmental concern on purchase of green products in retail.Procedia - Social and Behavioral Sciences 170, $99-108$.

Khare, A. (2015). Antecedents to green buying behaviour: A study on consumers in an emerging economy. Marketing Intelligence and Planning, 33(3), 309-329.

Kim, Y., and Choi, S.M., (2005). Antecedents of green purchase behavior: An examination of collectivism, environmental concern, and PCE. Advance Consumer Research, 32 (1), 592-599.

Kinnear, T.C., Taylor, J.B. and Ahmed, S.A. (1974). Ecologically concerned consumers: who are they?. Journal of Marketing, 38 (2), 20-24.

Ko, S.B. and Jin, B. (2017). Predictors of purchase intention toward green apparelproducts: A cross-cultural investigation in the USA and China. Journal of Fashion Marketing and Management: An International Journal, 21(1), 70-87, 
Kotchen, M.J., and Relling, S.D. (2000). Environmental attitudes, motivations, and contingent valuation of nonuse values: A case study involving endangered species. Ecological Economics, 32(1), 93-107.

Laufer, W. (2003). Social accountability and corporate greenwashing. Journal of Business Ethics, 43(3), $253-261$.

Leonidou, C.N., Katsikeas, C.S., and Morgan, N.A. (2013). Greening the marketing mix: do firms do itand does it pay off?.Journal of Academy of Marketing Science, 41(2), 151-170.

Lertpratchya, A.P., Besley, J.C., Zwickle, A., Takahashi, B. and Whitley, C.T. (2017). Assessing the role of college as a sustainability communication channel. International Journal of Sustainability in Higher Education, 18(7), 1060-1075.

Liu, M.T., and Liu, Y. (2020). Moral norm is the key An extension of the theory of planned behaviour (TPB) on Chinese consumers' green purchase intention. Asia Pacific Journal of Marketing and Logistics,doi: 10.1108/ APJML-05-2019-0285.

Martenson R (2007). Corporate brand image, satisfaction and store loyalty: a study of the store as a brand, store brands and manufacturer brands. International Journal Retailing and Distribution Management, 35(7), $544-555$.

Marvi, H.M., Minbashrazgah, M.M., Azim, Z., and Baghini, S.G. (2020). Knowledge foundation in green purchase behaviour:Multidimensional scaling method.Cogent Business and Management, 7(1), 1773676

Mishal, A., Dubey, R., Gupta, O.K., and Luo, Z. (2017). Dynamics of environmental consciousness and green purchasebehaviour: an empirical study. International Journal of Climate Change Strategies and Management, 9(5), 682-706

Moisander, J. (2007). Motivational complexity of green consumerism. International Journal of Consumer Studies, 31(4), 404-409.

Moravcikova, D., Krizanova, A., Kliestikova, J., and Rypakova, M. (2017). Green marketing as the source of the competitive advantage of the business. Sustainability, 9 (2218), 1-13.

Moser, A.K. (2015). Thinking green, buying green? Drivers of pro-environmental purchasing behavior. Journal of Consumer Marketing, 32(3), $167-175$.

Nguyen,T.M., Nham, P.T., and Hoang, V.N. (2019). The theory of planned behavior and knowledge sharing: A systematic review and meta-analytic structural equation modelling. VINE Journal of Information and Knowledge Management Systems, doi: https://doi.org/10.1108/ .

Nilsson, U.A.J. (2016). Green consumer behavior: being good or seeming good?. Journal of Product and Brand Management, 25(3), 1-21.

Oliver, R.L. (1999). Whence consumer loyalty? The Journal ofMarketing, 33-44.

Paul, J., Modi, A. and Patel, J. (2016). Predicting green product consumption using theory of planned behavior and reasoned action. Journal of Retailing and Consumer Services, 29(1), 123-134.

Prakash, G., and Pathak, P. (2016). Intention to buy eco-friendly packaged products among young consumers of India: A study on developing nation. Journal of Cleaner Production, doi: 10.1016/j.jclepro.2016.09.116.

Rahbar, E., and Wahid, N.A. (2011). Investigation of green marketing tools' effect on consumers' purchase behavior. Business Strategy Series, 12 (2), 73-83.

Saeednia, R.H., and Valahzaghard, K.S. (2012). A study to measure the impact of customer perception, quality, environment concern and satisfaction on green customer loyalty. Management Science Letters, 2(1), 2881-2888.

Sarkar, J.G., Sarkar, A., and Yadav, R. (2019). Brand it green: young consumers' brandattitudes and purchase intentions toward green brand advertising appeals. Young Consumers, 20(3), 190-207

Schmeltz, L. (2012). Consumer-oriented CSR communication: focusing on ability or morality? Corporate Communications: An International Journal, 17(1), 29-49. 
Sharma, A., and Foropon, C. (2019). Green product attributes and green purchase behavior: A theory of planned behavior perspective with implications for circular economy. Management Decision, doi: org/10.1108/MD-102018-1092.

Straughan, R.D., and Roberts, J.A. (1999). Environmental segmentation alternatives: A look at green consumer behavior in the new millennium. Journal of Consumer Marketing, 16(6): 558-75.

Sujith, T. S. (2017). Awarness of green marketing and its influence on buying behaviour of consumers in Kerala. International Journal of Scientific Research and Management (IJSRM), 5(7), 6156-6164.

Sukhi, M.N. (2016). Green product purchase intention: impact of green brands, attitude, and knowledge. British Food Journal, 118 (12), 2893-2910.

Tarkiainen, A., and Sundqvist, S. (2005). Subjective norms, attitudes and intentions of Finnish consumers in buying organic food. British Food Journal,107 (11), 808 - 822.

Taylor, S., and Todd, P. (1995). An integrated model of waste management behavior: A test ofhousehold recycling and composting intentions. Environment and Behavior, 27, 603-630.

Teng, C.C., Lu, A.C.Cand Huang, T.T. (2014). Drivers of consumers' behavioral intention toward green hotels.International Journal of Contemporary Hospitality Management,doi: org/10.1108/IJCHM-04-2017-0203.

Tenkasi, V.R, and Zhang, L. (2018). A Test of the Theory of Planned Behavior: Influencing Behavioral Change to go "Green". Research in Organizational Change and Development, 26(1), 127-165.

Thi Tuyet Mai, N. (2019). An investigation into the relationship between materialism and green purchase behavior in Vietnam and Taiwan. Journal of Economics and Development, 21(2), 247-258.

Tyagi, H. (2013). Emerging strategies of green marketing in India. Bookman International Journal of Accounts, Economics and Business Management, 2(2), 45-50.

Uddin, F.M.S and Khan, N.M. (2018). Young consumer's green purchasing behaviour: Opportunities for green marketing. Journal of Global Marketing. Retrieved from http://www.tandfonline.com/doi/abs/10.1080/ 08911762.2017.1407982. Last accessed on 5.6.2021.

Vermeir, I., and Verbeke, W. (2006). Sustainable food consumption: Exploring the consumer "attitude-behavioral intention" gap. Journal of Agricultural and Environmental Ethics, 19(2), 169-194.

Wu, S.I., and Chen, J.Y. (2014). A model of green consumption behavior constructed by the theory of planned behavior. International Journal ofMarketing Studies, 6(5), 119-132.

Yadav, R., and Pathak, G.S. (2016). Young consumers' intention towards buying green products in a developing nation: extending the theory of planned behaviour. Journal of Cleaner Production,135(1), 732-739.

Yadav, R. and Pathak, G.S. (2017). Determinants of consumers green purchase behavior in a developing nation: applying and extending the theory of planned behavior. Economics, 134(1), 114-122.

Zhang, X. and Dong, F. (2020). Why Do Consumers Make Green Purchase Decisions? Insights from a Systematic Review. International Journal of Environmental Research and Public Health, 17, 6607. 